\title{
Effects of Employee Commitment on Collectivism in the Workplace: Further Evidence
}

\author{
Asriansyah Siran Mawung ${ }^{1}$, Bambang Mantikei Jaya Budi ${ }^{2}$, Lelo Sintani ${ }^{3}$, \\ Agus Satrya Wibowo ${ }^{4}$
}

Abstract:

Purpose: Some industries whose products are considered to have a negative effect on health and environment, are categorized as controversial industries. Empirical studies in such studies have not been widely carried out.

Design/methodology/approach: This study was carried out in a controversial industry to examine the level of employee collectivism in the face of various challenges in this industry. The number of samples is 150 people, with the method of non purposive random sampling. Respondents were taken from several cigarette factories in Kudus. The method of analysis in this study is the multiple linear regression analysis, with SSPS testing reliability and validity, correlation, hypothesis testing, simultaneous effect and the coefficient of determination.

Findings: The results demonstrate that in this industry, employees are trying to increase collectivism to strengthen solidarity in the workplace.

Practical Implications: This findings can be used implementatively for management to improve the elements supporting the strengthening of employee commitment and increasing collectivism in the workplace. Theoretically, this finding is useful to know more about industrial relations and human resource management in controversial industries.

Originality/value: The study examines how individual commitments can unite employees to continue working in controversial industries, and whether individual commitment can strengthen fellow employee relations.

Keywords: Employee commitment, collectivism, controversial industries.

JEL code: $O 15$, M14.

Paper type: Research article.

\footnotetext{
${ }^{l}$ Faculty of Economics and Business, Universitas Palangka Raya, Indonesia email: ssmawung.upr@gmail.com

${ }^{2}$ Faculty of Economics and Business, Universitas Palangka Raya, Indonesia email: assatrya77@gmail.com

${ }^{3}$ Faculty of Economics and Business, Universitas Palangka Raya, Central Kalimantan, Indonesia.

${ }^{4}$ Faculty of Economics and Business, Universitas Palangka Raya, Central Kalimantan, Indonesia.
} 


\section{Introduction}

The concept of organizational commitment (OC) has long been considered important in management research because of its relationship with various outcomes that have the potential to impact the organization. Although much research on OC has been done in the West, Randall (1993) stated that "cross-cultural research on organizational commitment is a field of growth". Empirical testing of the role of employee commitment in various types of manufacturing, distribution and service industries has been carried out very much.

In addition, the development of the concept of commitment also seems to be based on arguments in normal industries (Meyer et al., 2004; Whitener, 2001; Bhatti and Qureshi, 2007). Knowledge of the unusual application of employees in industry, or what is called a controversial industry, seems to need to be further deepened. This is because the commitment to work in this kind of industry is not only to fulfill life needs and improve company performance in general (Rodrigo et al., 2016), but also dealing with negative perceptions of the effects of this controversial industry on social and environmental spheres (De Roeck and Delobbe, 2012).

In this context, efforts are needed to strengthen each other among fellow employees, and the development of collectivism in the workplace. Most studies in controversial industries highlight the influence and ethics of corporate social responsibility by this industry (Cai et al., 2012; Jo and Na, 2012; Kilian and Hennigs, 2014) in their efforts to find legitimacy (Palazzo, and Richter, 2005; Lindorff et al ., 2012; Fooks et al., 2011), and less highlighted the management of human resources at the employee level.

This study attempts to critically examine the theoretical application of employee commitment, which has received much attention from previous literature in the controversial industry. Industrial sectors that are considered controversial are sectors that are often involved in ethical, social, or environmental problems. Some examples of industries in this category are tobacco, alcohol, gambling, weapons, and adult entertainment, in addition to industries that are considered harmful to the environment such as the oil, nuclear, biotechnology and cement industries (Lindgreen et al., 2012; Reast et al., 2013).

This study was carried out in the tobacco industry, in the cigarette industry center in Indonesia, to examine whether the commitment of employees has an influence on the development of collectivism among their fellow-mutually reinforcing working in such controversial industries. Several previous studies have highlighted the tobacco industry in the context of CSR (Yoon et al., 2006; Hirschhorn, 2004), and comprehensive information about the influence of commitment to collectivism at the employee level has not been widely practiced. 


\section{Literature Review and Hypotheses}

\subsection{Affective Commitment}

Organizational commitment can be identified and divided into three forms, namely Affective Commitment, Normative Commitment and Continuity Commitment. Affective commitment represents an emotional attachment to an organization through identification and involvement. In general, Affective Commitment is divided into four categories: individual characteristics, structural characteristics, job characteristics, work experience. The Normative Commitment represents the sense of obligation to remain in an organization, and Continuity Comintment better describes the costs incurred or felt related to departure. Any feeling related to increase costs can be considered as an antecedent. Continuity Commitment can also be interpreted as an act of developing (Meyer and Allen, 1991).

This affective commitment is related to emotional attachment and involvement of employees in the organization. Employees who have a strong enough commitment will always work in the organization/company because of the emergence of a desire from within themselves and have an emotional connection that is sufficient to remain in the organization. This will determine a strong desire to be able to maximally contribute to the organization (Yuliani, Sintaasih, and Riana 2016).

\subsection{Continuance Commitment}

An organizational commitment means something that is more than just loyalty to a company, it can be said that an organizational commitment implies an active relationship between employees and companies or organizations. An employee who has a high commitment has the willingness to provide more energy and responsibility to support the welfare and success of the company where he works.

Continuance commitment shows that the employees consider the profit and loss as an indicator of the desire to continue working or leaving the organization. Continuous commitment shows the commitment of organizational members that are more determined by living costs. Thus, the greater the income of employees provided by the organization, the greater the job satisfaction and the work performance. The vice versa is also applicable. Employees with high continuance commitment persist in the organization because of the awareness of the large losses that will be experienced if they leave the organization.

\subsection{Normative Commitment}

It can be said that organizational commitment is a process that occurs in the drive of an employee in identifying the values, rules, and goals of an organization which includes feelings of participation in a job, loyalty, and confidence in the value of the organization. In order to be able to maintain its membership in the organization, the 
employee is ready to work hard, to perform obligations and responsibilities so that the organization's goals can be achieved, and will eventually be recorded in itself in the form of daily behavior.

Normative commitment describes the feeling of being obliged to keep working in an organization based on the existence of beliefs about "what is right" and related to moral issues. The Normative Commitment creates a feeling of obligation on the employee to give a reward for what he has received from the organization. Employees with high normative commitment will remain in the organization because they feel that there is an obligation or duty that is appropriate for the benefits that the organization has given to them. Normative Commitment is defined as a level where a person is psychologically bound to the organization where he/she is employed, through deepening organizational goals, values, and mission.

\subsection{Collectivism}

Collectivism has become a popular social science construct for around 100 years (Triandis, 2018). Collectivism can be interpreted to the extent that one sees themselves as one part of a group/organization (Triandis et al., 1988). This is an established concept of Eastern countries, but not in Western countries (Ryu, Lee, and Lee, 2011). Collectivism is a social pattern consisting of several individuals who have attachments and look at themselves as part of one or more collectives (family, coworkers, ethnic groups, nations) and the most motivated of the norms and duties imposed by the collective are willing to give priority to these collective goals above their own personal goals emphasizing their relationship with other members of this collectivism (Triandis 2018). Based on this description, the hypotheses proposed in this study are the following:

H1: Affective commitment has a positive effect on collectivism.

H2: Continuance commitment has a positive effect on collectivism.

H3: Normative commitment has a positive effect on collectivism.

\section{Research Methodology}

This study was carried out in a controversial industry, that is, industries whose existence and or products have a disputed effect between marketing and social norms. This industry includes the tobacco industry and the alcohol industry, where its products are considered to have a negative effect in health and environment. This study was empirically tested in the tobacco industry in Kudus, Indonesia, a district which is the main center of the cigarette industry in Indonesia. Conceptually, this study examines how individual commitments can unite employees to continue working in these industries, and whether individual commitments can strengthen fellow employee relations. 
Organizational commitment can be considered to be a force that helps each individual in identifying himself as part of the organization. This can be seen through three things, such as: accepting the values and objectives of an organization, the readiness and the willingness always try to the maximum in the name of the organization, and having the feeling of maintaining membership in the organization (Nurseha, 2007). Organizational commitment has three indicators: employee willingness, employee loyalty, and employee pride in the organization (Sopiah, 2008). Conceptually, organizational commitment can be seen as three dimensions: (1) there is trust and a great sense of acceptance of the goals and values of the organization; (2) there is a sense of desire from the employee to optimally do business for the organization/company; (3) there is a great desire to survive as a member in the organization/company (Akbar et al., 2017).

Commitment is love and loyalty which consists of: (1) unification with the company's goals and values; (2) the desire to remain in the organization; (3) the willingness to work hard on behalf of the organization (Sunarto, 2005).

The sample is 150 people, selected with the method of non purposive random sampling. Respondents were taken from several cigarette factories in Kudus. The analysis method in this study was carried out by multiple linear regression analysis, using the SPSS program, by testing reliability and validity, correlation, hypothesis testing, simultaneous effect and coefficient of determination.

\section{Results}

\subsection{Validity and Reliability}

The results of the statistical analysis show that the variables tested in this study have reliability values above the standard of 0.60 as suggested by Nunally and Bernstein (1967), with detailed values of 0.777 for affective commitment, 0.819 for continuance, 0.739 for normative commitment, and 0.687 for collectivism. Besides the value of instrument validity as reflected by the value of corrected item, total correlation shows items in affective commitment variables (6 items), continuance commitment (6 items), normative commitment (6 items) and collectivism (3 items) to be valid (Table 1).

Table 1. Reliability and Validity Statistics

\begin{tabular}{|l|l|l|l|l|}
\hline Variable & N of Items & Cronbach's Alpha & $\begin{array}{l}\text { Corrected Item- } \\
\text { Total Correlation }\end{array}$ & $\begin{array}{l}\text { Cronbach's Alpha if } \\
\text { Item Deleted }\end{array}$ \\
\hline AC & 6 & .777 & .420 & .612 \\
\hline CC & 6 & .819 & .433 & .606 \\
\hline NC & 6 & .739 & .464 & .589 \\
\hline COL & 6 & .687 & .477 & .574 \\
\hline
\end{tabular}




\begin{tabular}{|c|c|c|c|c|}
\hline Variable & $\mathrm{N}$ of Items & Cronbach's Alpha & $\begin{array}{l}\text { Corrected Item- } \\
\text { Total Correlation }\end{array}$ & $\begin{array}{l}\text { Cronbach's Alpha if } \\
\text { Item Deleted }\end{array}$ \\
\hline
\end{tabular}

\subsection{Correlation Test}

The results of the Pearson correlation test prove empirically that there is a correlational relationship between variables with a significance value below 0.01 . Correlation values for affective commitment (AC) and continuance commitment (CC), normative commitment (NC) are 0.287 and 0.300 . This means that there is a positive and significant relationship between the items tested. The correlational relationship between affective commitment and collectivism (COL) variables as the dependent variable is 0.359 . For the correlation between continuance commitment and normative commitment is 0.357 . While the relationship between continuance commitment and normative commitment with collectivism as the dependent variable is 0.333 and 0.370 , respectively.

Table 2. Correlation Test

\begin{tabular}{|l|l|l|l|l|}
\hline Variable & AC & CC & NC & COL \\
\hline AC & - & $.287^{* *}$ & $.300^{* *}$ & $.359^{* *}$ \\
\hline $\mathrm{CC}$ & - & - & $.357^{* *}$ & $.333^{* *}$ \\
\hline $\mathrm{NC}$ & - & - & - & $.370^{* *}$ \\
\hline $\mathrm{COL}$ & - & - & - & - \\
\hline *AC=affective commitment; CC=continuance commitment; NC=normative commitment; \\
$\begin{array}{l}\text { COL=collectivism } \\
* * \text { Correlation is significant at the } 0.01 \text { level (2-tailed) }\end{array}$
\end{tabular}

\subsection{Hypotheses Testing}

The first hypothesis states that there is a positive influence of affective commitment on collectivism. The test results show a coefficient of 0.237 with a significance level of 0.03. These results indicate a positive and significant effect of affective commitment on collectivism. Therefore, the first hypothesis is accepted. These results reveal that employees will be more likely to relate to the basic emotional attachment and involvement of employees in the organization. Employees who have a strong enough commitment will always work within the organization/company because of the emergence of a desire within themselves and have an emotional connection that is sufficient with the organization.

The second hypothesis states the positive influence of continuance commitment on collectivism. The test results show a coefficient of 0.181 with a significance level of 0.24 (Table 2). These results indicate a positive and significant influence of continuance commitment on collectivism. Then, the second hypothesis is accepted. 
This result confirms that employees will relate the profit and loss to the desire to continue working or leave the organization. This can be based in general on the cost of living. Thus, the greater the income of employees provided by the organization, the greater the job satisfaction, and their commitment to achievement, which in turn will affect the value of collectivism among fellow employees.

Table 3. Hypothesis Testing

\begin{tabular}{|c|c|c|c|c|c|c|}
\hline \multirow{2}{*}{\multicolumn{2}{|c|}{ Model }} & \multicolumn{2}{|c|}{ Unstandardized Coefficients } & \multirow{2}{*}{$\begin{array}{l}\text { Standardized Coefficients } \\
\text { Beta }\end{array}$} & \multirow[b]{2}{*}{$\mathrm{t}$} & \multirow[b]{2}{*}{ Sig. } \\
\hline & & B & Std. Error & & & \\
\hline \multirow[t]{4}{*}{1} & (Constant) & 1.650 & .934 & & 1.766 & .079 \\
\hline & $\mathrm{AC}$ & .293 & .096 & .237 & 3.055 & .003 \\
\hline & $\mathrm{CC}$ & .185 & .081 & .181 & 2.288 & .024 \\
\hline & $\mathrm{NC}$ & .304 & .104 & .234 & 2.937 & .004 \\
\hline
\end{tabular}

The third hypothesis states that the Normative Commitment has a positive influence on collectivism. The test results show a coefficient of 0.234 with a significance level of 0.04 . These results indicate a positive and significant Normative Commitment to collectivism. So, the third hypothesis is accepted. These results reveal the feeling of employees to continue working in an organization based on the existence of beliefs about "what is right" and related to moral issues. The Normative Commitment creates a feeling of obligation on the employee to give a reward for what he/she has received from the organization. In turn, this will affect the value of collectivism in the tobacco industry.

Furthermore, simultaneous testing through ANOVA between the effect of independent variables on the dependent variable shows an $\mathrm{F}$ value of 14.704 and a significance value of 0.00 (Table 4). These results indicate that there are significant influences, meaning that all affective commitment, continuance commitment, normative commitment variables simultaneously influence collectivism.

Table 4. ANOVA

\begin{tabular}{|l|l|l|l|l|l|l|}
\hline \multicolumn{2}{|l|}{ Model } & Sum of Squares & df & Mean Square & F & Sig. \\
\hline \multirow{4}{*}{1} & Regression & 22.258 & 3 & 7.419 & 14.704 & $.000^{\mathrm{a}}$ \\
\cline { 2 - 8 } & Residual & 73.670 & 146 & .505 & & \\
\cline { 2 - 7 } & Total & 95.928 & 149 & & & \\
\hline
\end{tabular}

a. Predictors: (Constant), NC, AC, CC

b. Dependent Variable: COM

The last test is testing the determination coefficient ( $\mathrm{R}$ Square) to reveal the amount of value that can be predicted by independent variables in the dependent variable. The test results show the adjusted R-square value of 0.216 . These results indicate 
that the dependent variable of affective commitment, continuance commitment, normative commitment is able to predict $21.6 \%$ of the dependent variable of collectivism (Table 4).

Table 4. Coefficient of Determination

\begin{tabular}{|l|l|l|l|l|}
\hline Model & $\mathrm{R}$ & $\mathrm{R}$ Square & Adjusted R Square & Std. Error of the Estimate \\
\hline 1 & $.482^{\mathrm{a}}$ & .232 & .216 &, 71034 \\
\hline
\end{tabular}

\section{Conclusion}

The test results show that 3 types of commitment are influencing the employee collectivism in controversial industries, precisely the tobacco industry, and these are affective, continuance and normative. Empirically, this study reveals that the higher the commitment, the higher the collectivism. Testing in a variety of normal industries can easily prove this as rationally. It is just that, in a controversial industry, where criticism of its existence is increasingly being voiced by a number of activists can make employees not feel at home in this kind of work environment. The results of this study demonstrate that in this industry, employees are trying to increase collectivism to strengthen solidarity in the workplace.

This finding can be used implementatively for management to improve the elements supporting the strengthening of employee commitment and increasing collectivism in the workplace. Theoretically, this finding is useful to know more about industrial relations and human resource management in controversial industries. Future studies are expected to be able to proportionally increase the number of samples according to the number of workers in the industry, and add to the various other controversial industries in longitudinal studies to find collectivism at the employee level.

\section{References:}

Akbar, A., Al Musadieq, M. and Mukzam, M.D. 2017. The Influence of Organizational Commitment to Performance (Study on PT Pelindo Surabaya Employees). Business Administration Journal, 47(2), 33-38.

Bhatti, K.K. and Qureshi, T.M. 2007. Impact of employee participation on job satisfaction, employee commitment and employee productivity. International review of business research papers, 3(2), 54-68.

Cai, Y., Jo, H. and Pan, C. 2012. Doing well while doing bad? CSR in controversial industry sectors. Journal of Business Ethics, 108(4), 467-480.

De Roeck, K. and Delobbe, N. 2012. Do environmental CSR initiatives serve organizations' legitimacy in the oil industry? Exploring employees' reactions through organizational identification theory. Journal of business ethics, 110(4), 397-412.

Fooks, G.J., Gilmore, A.B., Smith, K.E., Collin, J., Holden, C. and Lee, K. 2011. Corporate social responsibility and access to policy élites: an analysis of tobacco industry documents. PLoS medicine, 8(8). 
Hirschhorn, N. 2004. Corporate social responsibility and the tobacco industry: hope or hype? Tobacco control, 13(4), 447-453.

Jo, H. and Na, H. 2012. Does CSR reduce firm risk? Evidence from controversial industry sectors. Journal of business ethics, 110(4), 441-456.

Kilian, T. and Hennigs, N. 2014. Corporate social responsibility and environmental reporting in controversial industries. European Business Review, 26(1), 79-101.

Lindgreen, A., Maon, F., Reast, J. and Yani-De-Soriano, M. 2012. Guest editorial: Corporate social responsibility in controversial industry sectors. Journal of Business Ethics, 110(4), 393-395.

Lindorff, M., Jonson, E.P. and McGuire, L. 2012. Strategic corporate social responsibility in controversial industry sectors: The social value of harm minimisation. Journal of Business Ethics, 110(4), 457-467.

Meyer, J.P. and Allen, N.J. 1991. A three-component conceptualization of organizational commitment. Human resource management review, 1(1), 61-89.

Meyer, J.P., Becker, T.E. and Vandenberghe, C. 2004. Employee commitment and motivation: a conceptual analysis and integrative model. Journal of applied psychology, 89(6), 991.

Nunnally, J.C. and Bernstein, I.H. 1967. Psychometric theory. New York, McGraw-Hill.

Nurseha. 2007. Relationship Between Attitudes Against Changes in Organizational Structure with Commitments to Organizations in Employees of PT. Pertamina (Persero). Undergraduate thesis, UIN Syarif Hidayatullah.

Palazzo, G. and Richter, U. 2005. CSR business as usual? The case of the tobacco industry. Journal of Business Ethics, 61(4), 387-401.

Randall, D.M. 1993. Cross-cultural research on organizational commitment: A review and application of Hofstede's Value Survey Module. Journal of Business Research, 110, 91-110.

Reast, J., Maon, F., Lindgreen, A. and Vanhamme, J. 2013. Legitimacy-seeking organizational strategies in controversial industries: A case study analysis and a bidimensional model. Journal of Business Ethics, 118(1), 139-153.

Rodrigo, P., Duran, I.J. and Arenas, D. 2016. Does it really pay to be good, everywhere? A first step to understand the corporate social and financial performance link in Latin American controversial industries. Business Ethics: A European Review, 25(3), 286-309.

Ryu, S., Lee, E.J. and Jun Lee, W. 2011. A cross-cultural study of interfirm power structure and commitment: the effect of collectivism. Journal of Business \& Industrial Marketing, 26(2), 92-103.

Sopiah. 2008. Organizational behavior. Yogyakarta, Andi.

Sunarto. 2005. Employee Management. Yogyakarta, Amus.

Triandis, H.C. 2018. Individualism and collectivism. New York, Routledge.

Triandis, H.C., Bontempo, R., Villareal, M.J., Asai, M. and Lucca, N. 1988. Individualism and collectivism: Cross-cultural perspectives on self-ingroup relationships. Journal of personality and Social Psychology, 54(2), 323.

Whitener, E.M. 2001. Do "high commitment" human resource practices affect employee commitment? A cross-level analysis using hierarchical linear modeling. Journal of management, 27(5), 515-535.

Yoon, Y., Gürhan-Canli, Z. and Schwarz, N. 2006. The effect of corporate social responsibility (CSR) activities on companies with bad reputations. Journal of consumer psychology, 16(4), 377-390. 
Yuliani, K.A.I., Sintaasih, D.K. and Riana, I.G. 2017. Effect of Organizational Justice on Job Satisfaction and Organizational Commitment for Contract Employees at the Faculty of Economics. Udayana University, Management Forum STIMI Handayani Denpasar 14(1), 1-16. 